he finds interesting the idea that the increments paid should be adapted more closely to the advantages or disadvantages of the place of work. These are two ideas which would play havoc with the existing system if they were introduced, but Ginsburg insists that they 'deserve attention'.

No legislation of this kind exists in the western world where, broadly, employers pay what they have to pay to get the right labour. But the Soviet system-which has shown itself to work, if not always perfectly-contains some ideas which western countries might find it useful to adapt to their own use.

\title{
AN INTRODUCTION TO GREENLAND
}

[Review by Sylva Gethin* of Michael Banks' Greenland. Newton Abbot, David and Charles; Totowa, New Jersey, Rowman and Littlefield, 1975, 208 p, illus.]

With Greenland becoming increasingly popular as a goal for travellers, ranging from Arctic veterans to British schoolboys, and also beginning to figure in travel operators' brochures, there is very likely a need for a general account of the country, easily available and written in English. There are of course a wealth of publications in specialized fields, as well as expedition reports of differing length and quality, but Greenland should cater for the requirements of those who need a good, if superficial, general survey. In its 200 pages it packs in a surprising amount of topics-general geography, climate, population, biology, history, economy, and the social problems encountered by a society in the process of rapid change. There is a fairly detailed section on exploration with separate chapters dealing with the east coast, the north and the ice sheet. The book is also, for once, up to date in its information, except perhaps when it is claimed that 'For the Greenlanders, integration with Denmark is a natural and logical step, and their best chance of surviving, unhurt, in the technological age. What is so very pleasant and unusual in these fractious times is that the union has every appearance of being a love match.' I fear this idyllic picture may be somewhat misleading. The pages of the Greenland newspaper Atuagagdliutit-which, by the way, appears every week these days, not every two weeks-are full of references to an emerging struggle for 'home rule', and a commission has just been appointed which will look into the possibilities of transferring certain areas of government to the provincial council of Greenland. In fact, the Greenland minister has been quoted as saying that Greenland home rule will be a reality by April 1979. If the drilling that is projected off the west coast of Greenland should eventually produce oil, conflicts seem unavoidable.

Due to the compression of the material the book has become somewhat dry and enumerative and hardly falls into the 'not to be put down' category, but as an introduction for the traveller or wouldbe student of the country it should serve well. There is, however, the usual quota of mis-spelt Scandinavian personal and place-names. That a few other errors have crept in, such as the placing of the Arctic Circle at $67^{\circ} 30^{\prime}$ on p 11, is perhaps due to the pressure of a deadline because the book is on the whole well documented. It is also well illustrated and has a useful, if short, bibliography and index. I would plead for the inclusion in the former of Henrik Rink's Danish Greenland, its people and products, especially as his Tales and traditions of the Eskimo is listed. It remains an extremely readable and informative classic and was reprinted in 1974, published by C. Hurst and Company, as indeed were the Tales.

* Scott Polar Research Institute, Cambridge CB2 1ER.

\section{A TEXTBOOK ON SNOW AND GLACIERS}

[Review by Hans Röthlisberger* of Friedrich Wilhelm's Schnee- und Gletscherkunde. Berlin, New York, Walter de Gruyter, 1975, vii, 434 p, illus. (Lehrbuch der Allgemeinen Geographie, Bd 3, Teil 3.)]

When L. Lliboutry was writing his classic Traité de glaciologie more than 10 years ago he found it difficult even then to keep abreast of contemporary glaciological literature in view of the everincreasing number of publications on the subject. This new textbook by Friedrich Wilhelm,

* Abteilung für Hydrologie und Glaziologie, Voltastrasse 24, CH-8044 Zurich, Switzerland. 
primarily meant to replace the much older German textbooks by E. V. Drygalski and F. Machatschek (1942) and R. V. Klebelsberg (1949), attempts to review a wide field of specialized topics on snow and glaciers. It is possibly too great a task nowadays for a single author. Wilhelm, a geographer, claims to write for geographers, keeping physics to a minimum, but this principle proves to be of questionable merit in a field as interdisciplinary as glaciology.

The book covers the subjects of snow and glaciers in a fairly systematic way. The first part, concerning snow, contains ten main chapters: solid precipitation; structure and properties of the snow cover; measurements (various techniques for investigating the snow cover); surface features; decomposition (melting, ablation); avalanches; solid phase of the water cycle; snow, firn and equilibrium lines; world-wide distribution of the snow cover; implications for the natural and human environment. The nine main chapters on glaciers and continental ice sheets are: formation, structure and texture of glacier ice; movement of glaciers; thermal properties and regime of glaciers, ice sheets and ice shelves; mass balance; glacier variations; ice ages; classifications of glaciers; distribution of ice-covered areas; environmental importance.

The text is pleasant to read and easy to comprehend. The figures and photographs are numerous and of a high quality. The references are comprehensive if not complete. In spite of these merits some major sections are too sketchy and provide little substantial information. Various aspects of a particular problem are described in fairly general terms, and the reader is often referred to the bibliography for details. This must surely be a severe handicap for those German readers who do not know enough French or English to turn to L. Lliboutry's Traite de glaciologie, W. S. B. Paterson's Physics of glaciers or the numerous non-German papers cited in the text. It becomes necessary to revert to other sources because of the frequent textual inaccuracies, especially where equations and numbers are concerned. It would be beyond the scope of a short review to list them all, but I shall give a few examples.

Some of the inaccuracies are straightforward mistakes such as missing or wrong dimensions, and erroneous equations $\left(V_{m} / V_{s}\right.$ instead of $V_{s} / V_{m}$ on $\left.p 166\right)$. More serious is the fact that often the descriptive passages are also inaccurate and misleading; the statement on $\mathrm{p} 184$ that the location of the Bergschrund is determined by the break of the surface slope at the base of the headwall of the cirque is one example. Again, on p 192 the reader is referred to Table 34 in order to show that sections of a glacier in the firn region can be at the pressure melting point, but the temperatures of $-3^{\circ} \mathrm{C}$ and below given in Table 34 are all well below pressure melting point. The number giving ablation per degree-day of positive temperature is off by a factor of ten on $p 79$, while the range of values given is far too small. The definition for degree-day of positive temperature, though basically correct, does not comply with a more commonly used manner of determining this quantity. Furthermore, the references cited are few and randomly chosen for a subject as important as snow and ice melt in relation to meteorological factors.

To sum up, Schnee- und Gletscherkunde gives a fair idea of a vast variety of aspects of snow and glaciers but it lacks clarity and precision of detail. Readers who are interested in the general picture will find the large amount of details a burden, while those more deeply involved in the subject will miss the precision. Those new to the subject will be able to form a few ideas of what glaciology is all about and use the book advantageously as a guide to the original literature, but they must be warned to be aware of possible mistakes. To the senior glaciologist, who will readily notice its shortcomings, the book can nevertheless be recommended as a means of finding out about new developments as well as brushing up on some much older work. He may, like the reviewer, come across something he had missed before. 